\title{
Spheroidal degeneration of cornea and conjunctiva
}

\author{
A. GARNER, F. T. FRAUNFELdER,* T. C. BARRAS, and E. N. HINZPETER† \\ From the Department of Pathology, Institute of Ophthalmology, \\ University of London, and the External Disease Unit, Moorfields Eye Hospital, London
}

Small golden to yellow spherules in the cornea and conjunctiva have now been seen in people in every continent. There are, however, variations in the size, distribution, and number of the deposits, governed probably by environmental and nutritional factors, the duration of the condition, and the presence of other corneal lesions. Spheroidal deposits occurring in a band-shaped pattern across the central cornea are most common in regions in which the eyes are exposed to climatic extremes and the traumatic effects of wind-blown sand or ice (Bietti, Guerra, and Ferraris de Gaspare, I955; Freedman, 1965; Freedman, 1973b; Rodger, 1973; Young and Finlay, 1975). In geographical areas subject to much sunlight but spared the traumatic effects of wind-blown sand or ice it is common to see other concomitant corneal or conjunctival lesions, particularly pingueculae (Klintworth, 1972; Fraunfelder and Hanna, 1973), while in countries blessed with little actinic radiation this may almost be the rule (Garner, 1970, 1972). The prevalence of spheroidal degeneration in temperate climes characterized by low levels of sunlight has, however, not been reported, and the purpose of this paper is to document its incidence in the cornea and conjunctiva as seen in an English eye hospital and to comment on its association with pinguecula.

\section{Patients and methods}

From January to July 1975 almost 1000 random patients seen in the outpatient clinic at Moorfields Eye Hospital, London, were examined using a slit lamp for the presence of corneal or conjunctival droplets (Fig. I). Patients who had not spent at least three-quarters of their lives in Britain were excluded from the study. Photographs were taken using a macro camera (Brown I970) and a Zeiss photoslit lamp.

Thirty-two eye bank eyes and five corneas known to

*Visiting Professor, Institute of Ophthalmology. Present address : Department of Ophthalmology, University of Arkansas Medical Center, 430I West Markham, Little Rock, Arkansas 72201

†Visiting Worker, Institute of Ophthalmology. Present address: 2 Hamburg 20, Eisenlohrsweg 4, West Germany

Address for reprints: $\mathrm{Dr}$ A. Garner, Institute of Ophthalmology, Judd Street, London WCiH 9 QS contain spheroidal deposits were examined histologically, the tissue being fixed in formol saline and embedded in paraffin wax. Staining procedures included haematoxylin and eosin, Verhoeff-van Gieson, orcein, and Gomori's aldehyde fuchsin on untreated sections and sections predigested for six hours with pancreatic elastase (Fullmer, I960).

\section{Results}

The prevalence of conjunctival and corneal spheroidal droplets at various ages is shown in Fig. 2. The overall prevalence was $6 \cdot 5$ per cent with a predominance of males in patients over 50 years old in the ratio of 7 men to 3 women. Droplets were four times more common in those who spent much of their time out of doors than in patients who lived predominantly indoors. Analysis of the deposits according to the criteria introduced by Fraunfelder and Hanna (1973) showed that each of the 62 affected patients had conjunctival droplets while 12 also had corneal droplets. There was no sign of previous lesions in any of these patients.

Histological study was directed primarily to the connexion between spheroidal droplets and the altered connective tissue fibres seen in the frequently associated pingueculae (Fig. 3). Nine of the eye bank eyes had conjunctival pingueculae and three of these also included spheroidal deposits. The coarse curled fibres of pingueculae stained with each of the elastic stains used, and whereas pretreatment with elastase had minimal effect on the subsequent response to Verhoeff's stain or Gomori's aldehyde fuchsin technique it usually prevented staining with orcein (Figs 4 to 6). The spheroidal droplets, on the other hand, failed to react with either orcein or aldehyde fuchsin irrespective of predigestion with elastase. Their positive response to Verhoeff's stain was also unaffected by elastase (Figs 7 to 9). The results are collated in Table I.

\section{Discussion}

EPIDEMIOLOGY

A comparison of the English data with the results of an American study in the State of Arkansas 
conducted according to the same criteria (Fraunfelder and Hanna, 1973) shows a considerable difference at all ages in the prevalence of spheroidal degeneration (Fig. Io). Of the environmental factors that were considered in the aetiology of the deposits snly the amounts of actinic radiation in Arkansas and Britain are significantly different. This, together with the finding that a majority of the English patients with droplets spent much of their lives out of doors, supports the suggestion that exposure to sunlight is of pathogenic importance. Other geographical areas where the prevalence of spheroidal degeneration is high also have, among other things, much sunlight (Table II). Possibly the prevalence of the deposits in the general population in England is less than would seem from our data since our study was undertaken on outpatients to an eye hospital, who were therefore a selected group.

\section{PATHOLOGY}

Several workers have commented on the concomitance of spheroidal degeneration in the cornea and pinguecula (Klintworth, I972; Fraunfelder and Hanna, r973) and their similar staining proper- ties (Brownstein, Rodrigues, Fine, and Albert, I973; Rodrigues, Laibson, and Weinreb, I975). Since apparently identical deposits have long been known to occur in the conjunctival tissue overlying pingueculae (Fuchs, r891; Parsons, I904; Hogan and Zimmerman, I962; Klintworth, 1972) it has been proposed that both corneal and

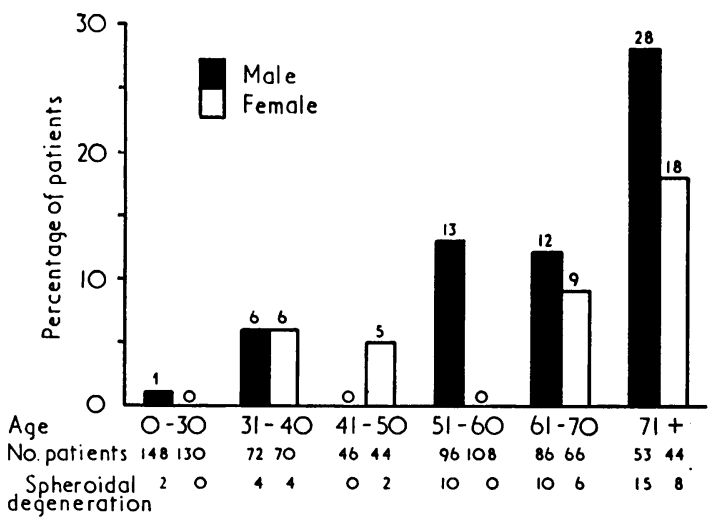

FIG. 2 Prevalence of spheroidal droplets in conjunctiva and/or cornea in British subjects related to age and sex 


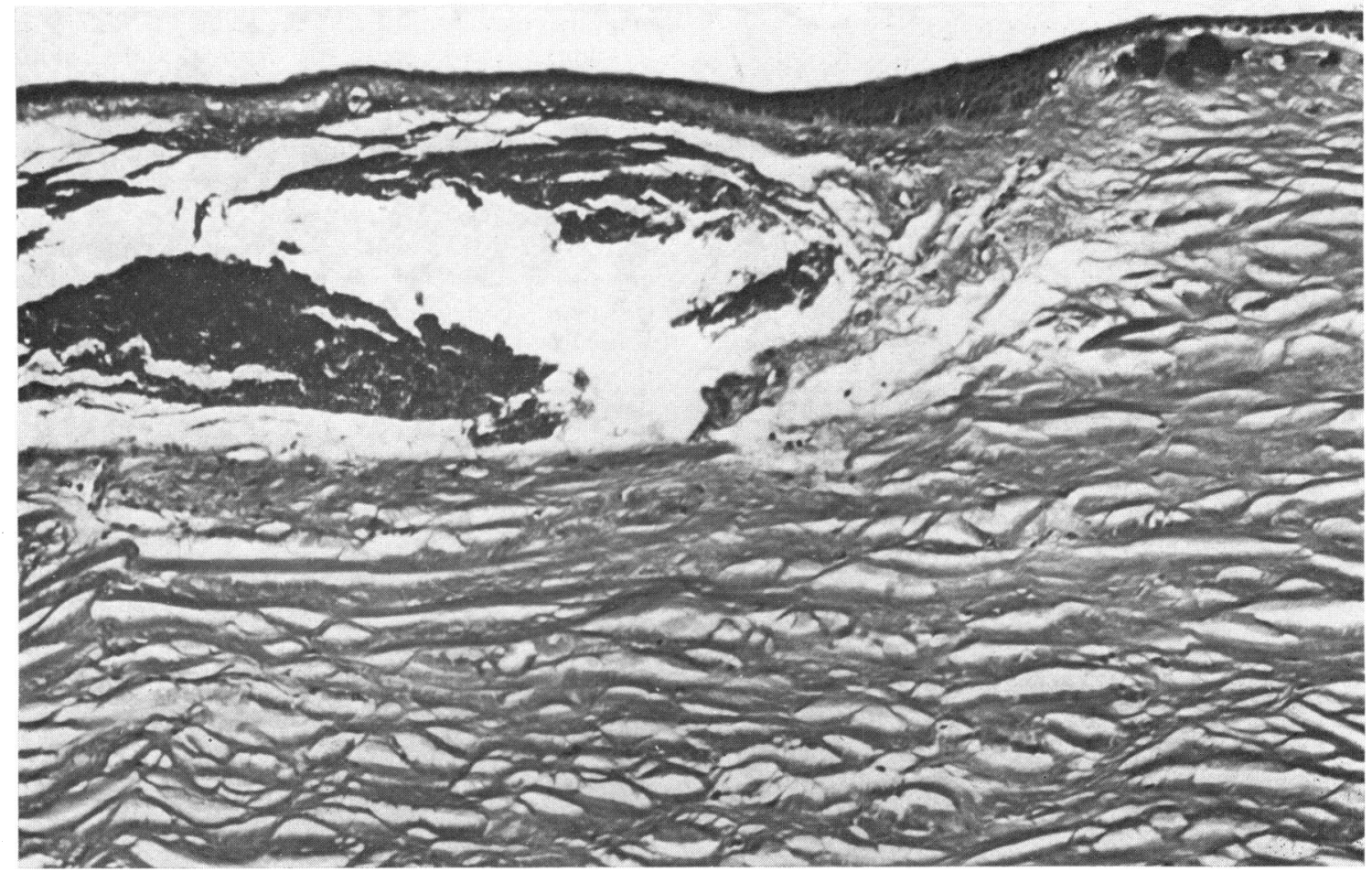

FIG. 3 Section showing hyaline droplets immediately beneath epithelium of corneal periphery associated with coarse degenerate fibres of a bulbar conjunctival pinguecula. Verhoeff-van Gieson. $\times$ I 5

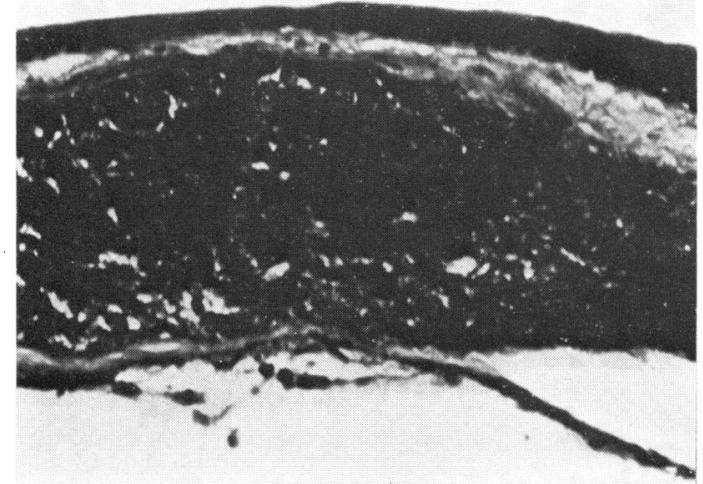

$(4 a)$

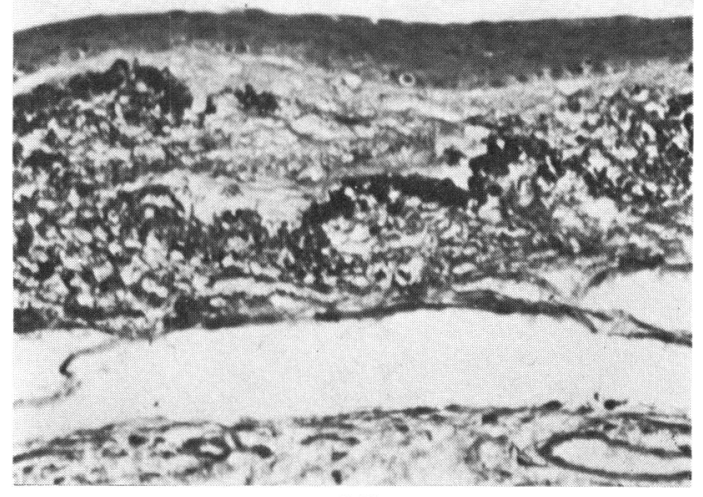

$(4 b)$

FIG. 4 Pinguecula. (a) Pseudoelastic fibres stain intensely with Verhoeff's haematoxylin. (b) Pretreatment with elastase for 6 hours partially inhibits staining reaction but ccarse convoluted fibres continue to react. Verhoeff-van Gieson. $\times 195$

conjunctival droplets are the result of degenerative changes in the stromal collagen (Klintworth, 1972; Brownstein and others, 1973; Christensen, 1973; Rodrigues and others, 1975). This concept has much in its favour. Our finding, however, that despite a common propensity to stain by Verhoeff's procedure for elastic the ability of pingueculae to react with other elastic stains such as orcein and aldehyde-fuchsin is not shared by the spheroidal deposits, does suggest that the transition from degenerative collagen to spheroidal droplets is due to more than a simple process of fibrillar disintegration. Adequate explanation of these staining differences requires a better understanding of the elastotic change seen in pinguecula formation and more information concerning the chemistry of the 


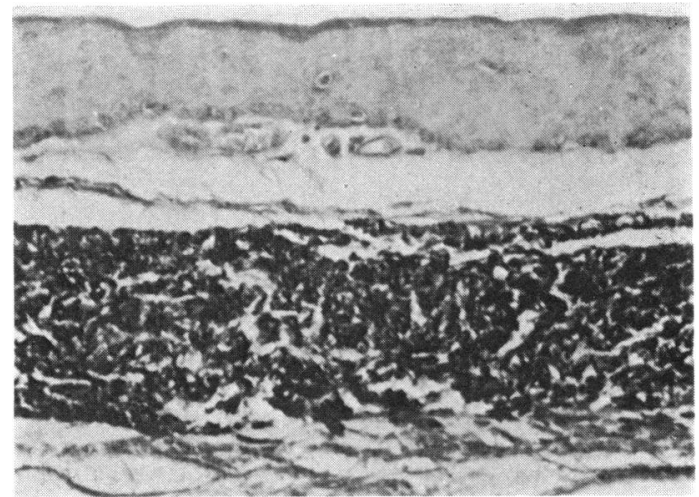

FIG. 5 Pinguecula. Abnormal fibres stain blue with aldehyde-fuchsin and, apart from some less coarse fibres, are essentially unaffected by elastase. Gomori's aldehyde-fuchsin. $\times 195$ staining reactions, but they do point to a difference in composition between the deposits and elastotic collagen. The earlier finding of tryptophan and appreciable amounts of tyrosine and sulphurcontaining amino-acids in the deposits (Garner, 1970; Klintworth, 1972; Brownstein and others, 1973; Garner, Morgan, and Tripathi, 1973) underlines this disparity, since these amino-acids are either absent or minimal in elastic tissue and collagen. The electron microscopy studies of Hanna and Fraunfelder (1972) may be relevant in this context, since they concluded that the spheroidal droplets represent the condensation of a granular material secreted by abnormal fibrocytes and deposited on collagen fibrils. Hogan and Alvarado (1967) have also commented on the presence of a non-collagenous protein in the spheroidal deposits. The addition of a second

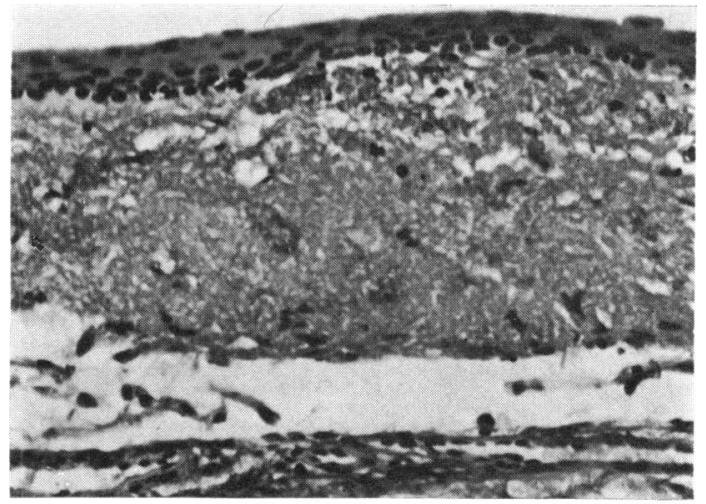

(6b)

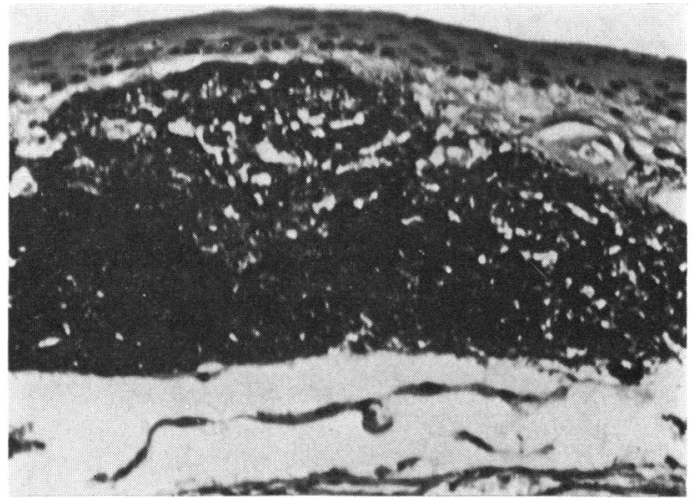

$(6 a)$

FIG. 6 Pinguecula. Positive staining with orcein largely prevented by predigestion with elastase. (a) Without elastase; (b) with elastase. Orcein. $\times 195$

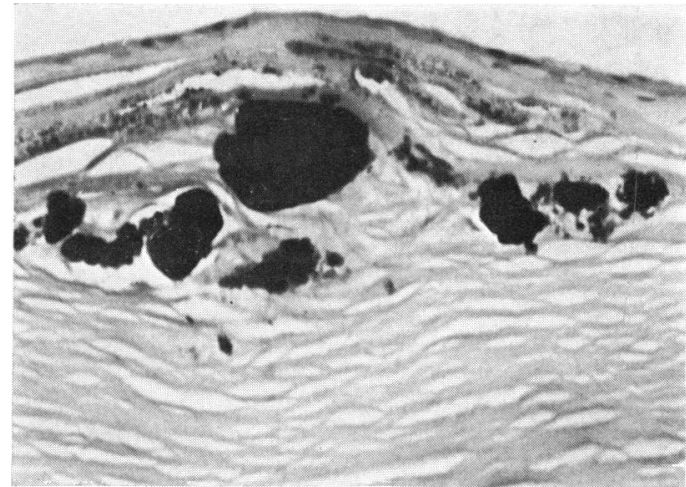

$(7 a)$

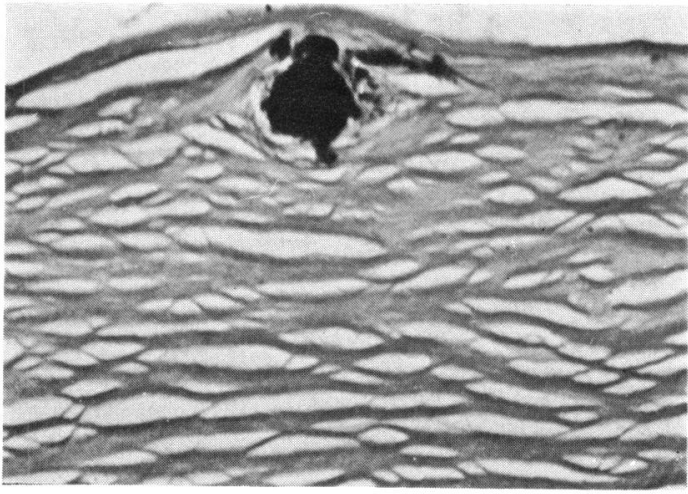

$(7 b)$

FIG. 7 Spheroidal droplets in cornea stain intensely with Verhoeff's haematoxylin and are unaffected by pretreatment with elastase. (a) Before elastase; (b) after elastase. Verhoeff-van Gieson. $\times 195$ 
protein, from whatever source, to the altered collagen fibres of a pinguecula (or to altered corneal stroma) might account for the somewhat different staining properties.

With regard to the staining properties of the pingueculae themselves, it is to be noted that we observed variable but generally marginal loss of ability to react with Verhoeff's haematoxylin and aldehyde-fuchsin as a result of predigestion with elastase and complete inhibition of orcein staining in such preparations. This effect of elastase is at slight variance with the usual statement that the fibres of a pinguecula are resistant to this type of enzymatic activity (Cogan, Kuwabara, and Howard, 1959) and is not easily explained, although it is of

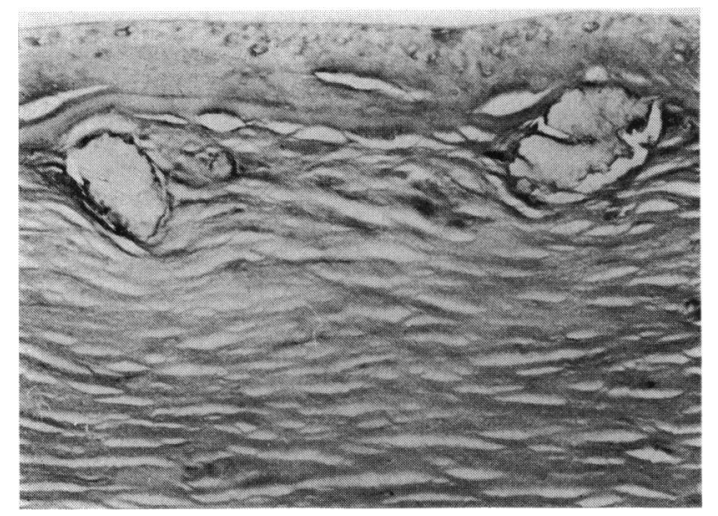

FIG. 8 In contrast to fibres of pingueculae, spheroidal droplets do not react with Gomori's aldehyde-fuchsin. $\times 130$

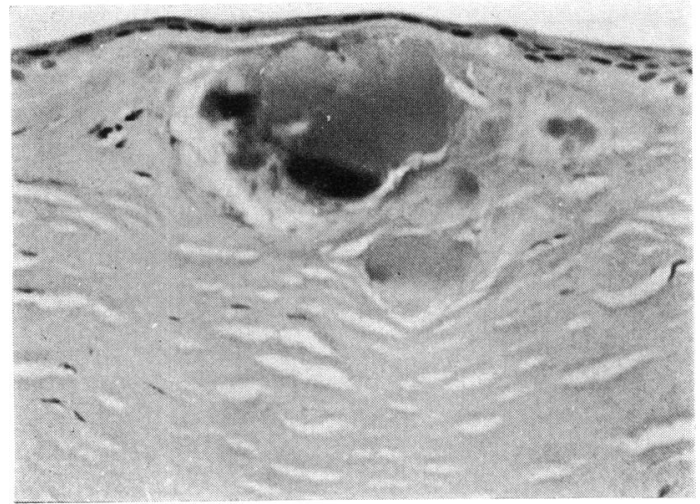

FIG. 9 Section of spheroidal droplets in cornea showing absence of staining with orcein. $\times 195$

interest that Lever (1967) states that elastotic fibres in the skin are digested.

\section{NOMENCLATURE}

Increased interest on the part of a number of investigators coupled with a persistent lack of crucial data has led to a profusion of names for the hyaline deposits. The term keratinoid, introduced by Garner (1970, 1972), has not found general acceptance and, in the light of subsequent evidence linking the deposits with elastotic degeneration of collagen, is probably best abandoned. Some recent terms such as proteinaceous degeneration (Christensen, 1973) are too vague, whereas others, such as actinic (Klintworth, 1972) or climatic (Freedman, 1973a) keratopathy, are not only

Table I Staining reactions for elastic tissue in patients with pingueculae and/or corneal droplets

\begin{tabular}{|c|c|c|c|c|c|c|c|c|c|c|}
\hline \multirow{3}{*}{$\begin{array}{l}\text { Case } \\
\text { no. }\end{array}$} & \multicolumn{6}{|c|}{ Pingueculae } & \multicolumn{4}{|c|}{ Spheroidal droplets } \\
\hline & \multicolumn{3}{|c|}{ Before elastase } & \multicolumn{3}{|c|}{ After elastase } & \multicolumn{2}{|l|}{ Verhoeff } & \multirow{2}{*}{$\begin{array}{l}\text { Aldehyde- } \\
\text { fuchsin }\end{array}$} & \multirow{2}{*}{ Orcein } \\
\hline & Verhoeff & $\begin{array}{l}\text { Aldehyde- } \\
\text { fuchsin }\end{array}$ & Orcein & Verhoeff & $\begin{array}{l}\text { Aldehyde- } \\
\text { fuchsin }\end{array}$ & Orcein & $\begin{array}{l}\text { Before } \\
\text { elastase }\end{array}$ & $\begin{array}{l}\text { After } \\
\text { elastase }\end{array}$ & & \\
\hline I & & + & + & & & - & & & & \\
\hline 2 & & + & + & & & - & & & & \\
\hline 3 & & + & & & & & & & & \\
\hline 4 & + & & + & \pm & & - & & & & \\
\hline 5 & + & + & + & + & + & - & & & & \\
\hline 6 & + & + & + & + & + & - & & & & \\
\hline 7 & + & + & + & + & + & - & + & & - & - \\
\hline 8 & + & & + & \pm & & \pm & + & + & & - \\
\hline 9 & + & & + & & & - & + & & & - \\
\hline 10 & & & & & & & + & + & - & - \\
\hline I I & & & & & & & + & + & - & - \\
\hline 12 & & & & & & & + & + & - & - \\
\hline 13 & & & & & & & \pm & \pm & - & - \\
\hline 14 & & & & & & & $\bar{t}$ & $t$ & - & - \\
\hline
\end{tabular}


unproved but are also unduly restrictive since they do not account for the corneal deposits secondary to other corneal disease. Until the nature of the deposits is known and their aetiology substantiated it may be better to use a purely descriptive term such as spheroidal degeneration or droplet keratopathy.

\section{Summary}

A study of almost 1000 outpatients at a London eye hospital showed the presence of asymptomatic yellowish, spheroidal deposits in the peripheral cornea or conjunctiva, or both, in about 6 per cent, with a preponderance of males and older subjects

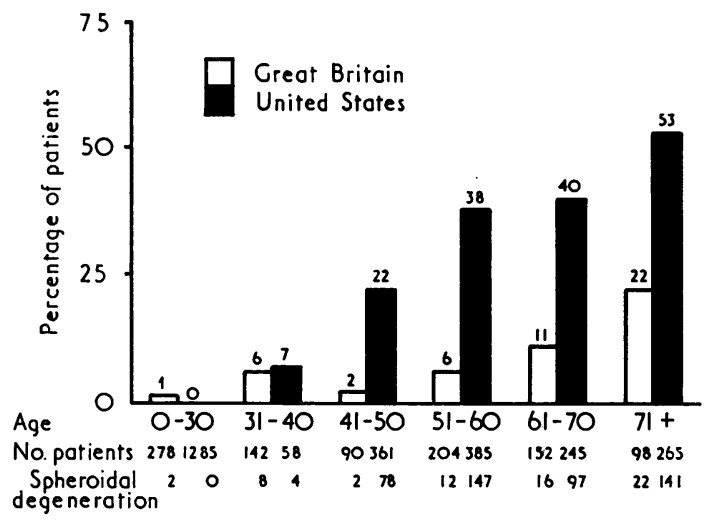

FIG. Io Comparison of prevalence of spheroidal droplets in conjunctiva and/or cornea in Great Britain and United States of America at various ages
Table II Reported prevalence of spheroidal droplets in various parts of the world (not age-or sex-matched)

\begin{tabular}{|c|c|c|}
\hline $\begin{array}{l}\text { Geographical } \\
\text { location }\end{array}$ & $\begin{array}{l}\text { Prevalence } \\
\text { of spheroidal } \\
\text { droplets in } \\
\text { general } \\
\text { population } \\
\text { (percentage) }\end{array}$ & Reference \\
\hline $\begin{array}{l}\text { Dahlak Island, } \\
\text { Ethiopia }\end{array}$ & 57 & Rodger, 1973 \\
\hline $\begin{array}{l}\text { Nama, South-West } \\
\text { Africa }\end{array}$ & 31 & Freedman, J., I973b \\
\hline Arkansas, USA & 18 & $\begin{array}{c}\text { Fraunfelder and } \\
\text { Hanna, 1973 }\end{array}$ \\
\hline Labrador, Canada & I I & Freedman, A., 1965 \\
\hline Labrador, Canada & 14 & $\begin{array}{l}\text { Young and Finlay, } \\
1975\end{array}$ \\
\hline London, England & 6 & Present study \\
\hline
\end{tabular}

among those affected. This prevalence is less than is observed in people in countries exposed to higher levels of sunlight.

Histological study of the deposits showed some tinctorial similarities with the pseudoelastic fibres of pingueculae, with which they were sometimes associated, but also significant differences suggesting that the spheroidal deposits might be a composite of degenerate collagen and a second noncollagenous protein.

Until a more precise terminology is feasible we suggest that a purely descriptive name such as spheroidal degeneration or droplet keratopathy should be used to describe this entity.

\section{References}

BIETTI, G. B., GUERRA, P., and FERRARIS DE GASPARE, P. F. (I955) Bull. Soc. franf. Ophtal., 68, IOI BRown, N. A. (1970) Brit. F. Ophthal., 54, 697

Brownstein, S., Rodrigues, M. M., Fine, B. S., and Albert, e. N. (1973) Amer. F. Ophthal., 75, 799

Christensen, G. R. (1973) Arch. Ophthal. (Chic.), 89, 30

COGAN, D. G., KUWABARA, T., and HOWARD, J. (1959) Ibid., 6r, 388

FREEDMAN, A. (1965) Ibid., 74, 198

(1973a) Ibid., 89, 193

FREEDMAN, J. (1973b) Brit. F. Ophthal., 57, 688

FRAUNFELDER, F. T., and HANNA, c. (1973) Amer. F. Ophthal., 76, 41

FUCHS, E. (1891) v. Graefes Arch. Ophthal., 37, I 43

Fullmer, H. M. (1960) $\mathcal{F}$. Histochem. Cytochem., 8, 290

GARNER, A. (1970) Brit. F. Ophthal., 54, 769

- (1972) Eye, Ear, Nose Thr. Monthly, 51, 299

-, MORgan, G., and Tripathi, R. c. (1973) Arch. Ophthal. (Chic.), 89, i98

hanNa, C., and FRAUnfelder, F. T. (1972) Amer. F. Ophthal., 74, 829

hogan, M. J., and Alvarado, J. (1967) Arch. Ophthal. (Chic.), 78, 174

-, and zimmerman, L. E. (I 962) 'Ophthalmic Pathology', 2nd ed., p. 253. Saunders, Philadelphia

klintworth, G. K. (1972) Amer. Y. Path., 67, 327

LEVER, W. F. (I 967) 'Histopathology of the Skin', 4th ed., p. 266. Lipincott, Philadelphia

PARSONS, J. H. (1904) 'The Pathology of the Eye', vol. I, p. 97. Hodder \& Stoughton, London

RODGER, F. C. (I973) Brit. F. Ophthal., 57, 657

RODRIGUeS, M. M., LAIBSON, P. R., and WeINREB, S. (1975) Arch. Ophthal. (Chic.), 93, I I I

YOUNG, J. D. H., and FINLAY, R. D. (1975) Amer. F. Ophthal., 79, 129 